\title{
Rodzina seniorska - nowa propozycja definicyjna w kontekście prognoz demograficznych i przemian funkcji rodziny
}

Senior family - new understanding in the context of demographic changes and family functioning

Abstract: Demographic changes, leading to an aging population around the world, largely influence on family functioning and the inner relationships. It affects particularly dependent members of the family - children and the elderly. Protective function of the family is under special modifications, what is obvious when analyzing the situation of the eldest members of family. All these factors may lead to modification of senior family definition, which will be couch according to actual relationship and caring, rather than on blood ties. The aim of the presentation is to present the contemporary transformations of the family, including senior, showing it in the context of alternative forms of family life and to present and discuss new proposals for the definition of the senior family, which is based on emotional bonds and care, rather than kinship. There are also presented the consequences of such an evolution in senior family understanding.

Keywords: ageing, seniors, senior family, senior care

Dane statystyczne są bezlitosne dla tzw. tradycyjnego modelu rodziny. Liczba rozwodów w Polsce rośnie w dość szybkim tempie. To zjawisko dotyka rów- 
nież małżeństw z długoletnim stażem ${ }^{1}$. Ich liczba nie wzrosła lawinowo, choć były takie prognozy, jednak jakość życia małżeństw po 60 -ce również pozostawia wiele do życzenia - oddzielne spędzanie czasu, osobne sypialnie lub łóżka, podział lodówki, obniżona tolerancja wobec siebie nawzajem. Przy postępującej liczbie rozwodów rośnie też liczba tzw. związków rekonstruowanych oraz związków partnerskich nieformalnych, również wśród seniorów ${ }^{2}$. W grupie osób posiadających dzieci ta skłonność do rekonstrukcji rodziny - formalnej i nieformalnej - może prowadzić do rozmywania się odpowiedzialności za opiekę nad osobami zależnymi, czyli dziećmi i osobami starszymi. W przypadku dzieci łatwiej jest określić prawną i pozaformalną odpowiedzialność za opiekę nad nimi. Dodatkowo istnieją dość skuteczne instrumenty prawne, pozwalające reagować w sytuacji zaniedbywania opieki nad dziećmi.

Inaczej wygląda sytuacja osób starszych, które często, mając po kilkoro dzieci, w ostateczności zostają samotne, pozbawione codziennego wsparcia w najprostszych życiowych działaniach, takich jak zakupy, dojazd do lekarza, wsparcie w higienie, oraz towarzyszenia. Zakładając, że każdy senior dąży do tego, żeby jak najdłużej zachować autonomię, oraz biorąc pod uwagę stale poprawiające się wskaźniki stanu zdrowia i sprawności należy jednak postawić pytanie, kto ostatecznie jest odpowiedzialny za seniora niewydolnego życiowo? Możemy przyjąć, że są trzy możliwe odpowiedzi na to pytanie - senior, rodzina i państwo. Pozostawiając na marginesie rozważania o roli państwa i seniora w zaspokajaniu potrzeb w starości, pragnę skoncentrować swoje rozważania na kwestii rodziny seniorskiej - jak powinna być ona ujmowana w sytuacji, gdy coraz częściej przedstawiciele młodszych pokoleń migrują w celach zarobkowych, izolują się od najstarszych członków rodziny lub też pozwalają sobie na niestosowne wobec nich zachowania.

Prognozuje się, że wraz z upływem kolejnych lat osoby starsze będą coraz powszechniej prowadzić jednoosobowe gospodarstwa domowe. Obecnie aż 40\% seniorów to osoby mieszkające samodzielnie. Do 2050 ma ich być po-

\footnotetext{
1 Liczba rozwodów, na które decydują się ludzie po 50. roku życia, z 20-, 30-letnim stażem małżeńskim, od dwóch dekad systematycznie w Polsce rośnie. Statystyczny rozwodnik ma przeciętnie 40-41 lat, kobieta 38-39 lat. W liczbach bezwzględnych wciąż najszybciej i najczęściej kończą się małżeństwa młode, ale w 2014 rozpadło się już 17,5 tys. - czyli trzykrotnie więcej niż w 1990 - związków mających za sobą ponad 20 wspólnie przeżytych lat (ogółem rozwiodło się 66,6 tys. par), Niezmiennie wśród nowo zawartych związków ok. $82 \%$ stanowią małżeństwa pierwsze, tj. panien z kawalerami (na wsi jest ich około $88 \%$ ). Pozostałe $18 \%$ to małżeństwa kolejne. Por. GUS, Podstawowe informacje o rozwoju demograficznym Polski do 2014 roku, Warszawa 2015.

2 P. Szukalski, Małżeństwa zawierane w starszym wieku - szkic demograficzny, [w:] Starość darem, zadaniem i wyzwaniem, red. A. Zych, Sosnowiec-Dąbrowa Górnicza 2014.
} 
nad połowa w wieku $65+{ }^{3}$. Pewna część seniorów będzie na pewno miała dostęp do opieki rodziny lub instytucji opiekuńczych. Ale będzie też grupa osób w wieku 65+, które zostaną pozostawione same sobie ${ }^{4}$. Dlatego będą potrzebne jakieś alternatywne rozwiązania w kwestiach organizacji życia codziennego, opieki medycznej, prowadzenia domu, a co za tym idzie, wpłynie to na pojawienie się nowych konstelacji społecznych, takich jak rodzina seniorska w opisywanym w tym artykule rozumieniu.

Celem niniejszego artykułu jest przegląd możliwych stanowisk na temat rodziny seniorskiej w kontekście systemowego jej rozumienia oraz próba sformułowania definicji rodziny seniorskiej w kontekście przemian, dotykających rodzinę jako grupę społeczną.

\section{Różnorodność rozumienia rodziny}

Systemowe podejście do kwestii rodziny wydaje się dobrym narzędziem do opisu zachodzących w niej procesów oraz całościową koncepcją, ujmującą mnogość elementów. W podejściu systemowym obowiązuje zasada emergencji. Oznacza to, że rodzina jest traktowana jako pewna całość, stanowiąca jakościowo coś więcej niż sumę jej poszczególnych części. Członkowie rodziny mogą być jednocześnie elementami innych systemów, szeroko rozumianego otoczenia społecznego. Pomiędzy elementami zachodzą określone oddziaływania, a struktury poszczególnych systemów dążą do dynamicznej równowagi. Systemy oscylują pomiędzy stałością a skłonnością do zmiany.

Elementy systemu, członkowie rodziny, tworzą strukturę i specyfikę tej struktury poprzez pełnienie określonych ról i wypełnianie zadań im przypisanych. Rodzina w swoim istnieniu spełnia określone cele, którym podporządkowane są zasady regulujące działanie danego systemu rodzinnego ${ }^{5}$. W ramach systemowego rozumienia rodziny określać można role jej członków, ich wzajemne

3 Jak będzie wyglądała starość dzisiejszych 30-latków? Rozmowa zprof. Piotrem Błędowskim, http://weekend.gazeta.pl/weekend/1,138262,18364753,jak-bedzie-wygladala-staroscdzisiejszych-30-latkow-prof-piotr.html (25.07.2015).

4 „W 2050 r. liczba ludności Polski wyniesie $33 \mathrm{mln} 951$ tys. W porównaniu do stanu w roku bazowym 2013 oznacza to zmniejszenie liczby ludności o 4,55 miliona, tj. o 12\%. Oprócz ujemnego przyrostu naturalnego będziemy obserwować dalsze niekorzystne zmiany w strukturze ludności według wieku oraz zmniejszanie się liczebności kobiet w wieku rozrodczym. Osoby w wieku 65 i więcej lat życia będą stanowiły prawie 1/3 populacji, a ich liczba wzrośnie o 5,4 miliona w porównaniu do 2013 r.", za: Prognoza ludności na lata 20142050, GUS, Warszawa 2014, s. 109.

$5 \quad$ M. Ryś, Kształtowanie się poczucia własnej wartości i relacji z innymi w różnych systemach rodzinnych, „Kwartalnik Naukowy Fides et Ratio” nr 2(6)2011, s. 65-84. 
relacje, granice rodziny(wewnętrzne i zewnętrzne), otwartość, podsystemy, cyrkularność, fazy rozwoju i dynamikę relacji.

Podejście systemowe zdaje się być nieetykietującym sposobem opisu procesów i relacji, jakie zachodzą w rodzinie. Używając specyficznych dla niego pojęć, jak granice, emergencja, sieci, otwartość, cyrkularność, ekwifinalność czy ekwipotencjalność, można dokonać szczegółowej analizy procesów zachodzących $\mathrm{w}$ rodzinie, $\mathrm{z}$ uwzględnieniem ich dynamiki, a nie wyłącznie problematyczności. Jest to jeden $\mathrm{z}$ aspektów naukowych, jakie stanowią pewną przesłankę do zaproponowania nowej definicji rodziny seniorskiej.

Kolejna przesłanka odwołuje się do prawnej ochrony rodziny, począwszy od ochrony konstytucyjnej, przez Kodeks rodzinny i opiekuńczy, Kodeks cywilny, Kodeks karny, a także cały szereg ustaw szczegółowych, dotyczących kwestii związanych z różnorodnymi aspektami funkcjonowania rodzi$n y^{6}$. Należy zaznaczyć, że rodzina w polskim prawodawstwie jest zdefiniowana niejednoznacznie i bardzo szeroko. Przykładowo Kodeks rodzinny i opiekuńczy określa rodzinę jako związek małżeński, którego obowiązkiem jest troska o dzieci, które w ramach tego związku się rodzą7. Z kolei Ustawa o pomocy społecznej definiuje rodzinę jako wszystkie osoby wspólniezamieszkujące i prowadzące wspólne gospodarstwo domowe, niekoniecznie ze sobą spokrewnione ${ }^{8}$. Dokładny wykaz osób, które można zaliczyć do rodziny, można znaleźć w Ustawie o emeryturach i rentach z Funduszu Ubezpieczeń Społecznych, gdzie wśród osób uprawnionych do świadczeń - członków rodziny - wymieniane są dzieci własne i przysposobione, pasierbowie, wnuki i rodzeństwo przyjęte na wychowanie i utrzymanie przed osiągnięciem pełnoletniości, dzieci przyjęte na wychowanie w rodzinie zastępczej, rodzice oraz małżonek (wdowa lub

6 Pośród tych ustaw można wymienić między innymi: Ustawę z dnia 12 marca 2004 roku o pomocy społecznej, Ustawę z dnia 26 czerwca 1974 roku - Kodeks Pracy, Ustawę z dnia 26 października 1982 roku o postępowaniu w sprawach nieletnich, Ustawę z dnia 7 stycznia 1993 roku o planowaniu rodziny, ochronie płodu ludzkiego i warunkach dopuszczalności przerywania ciąży, Ustawę z dnia 28 listopada 2003 roku o świadczeniach rodzinnych, Ustawę z dnia 29 lipca 2005 roku o przeciwdziałaniu przemocy w rodzinie, Ustawę z dnia 7 września 2007 roku o pomocy osobom uprawnionym do alimentów, Ustawę z dnia 9 czerwca 2011 roku o wspieraniu rodziny i systemie pieczy zastępczej.

„Oboje małżonkowie obowiązani są, każdy według swych sił oraz swych możliwości zarobkowych i majątkowych, przyczyniać się do zaspokajania potrzeb rodziny, którą przez swój związek założyli. Zadośćuczynienie temu obowiązkowi może polegać także, w całości lub w części, na osobistych staraniach o wychowanie dzieci i na pracy we wspólnym gospodarstwie domowym" - art. 27 Ustawy z dnia 25 lutego 1964 roku Kodeks rodzinny i opiekuńczy (Dz. U. z 1964 r., Nr 9, poz. 59 ze zm.).

8 Rodzina to „osoby spokrewnione lub niespokrewnione, pozostające w faktycznym związku, wspólnie zamieszkujące i gospodarujące” - art. 6 ust. 14 Ustawy z dnia 12 marca 2004 roku o pomocy społecznej (Dz. U z 2 lipca 2008 r. Nr 115 poz. 728 - tekst jednolity). 
wdowiec) - nawet wówczas, gdy przed śmiercią orzeczony został rozwód lub separacja ${ }^{9}$. W rozumieniu polskiego prawa rodzinnego relacje, które świadczą o byciu rodziną, to małżeństwo, pokrewieństwo, powinowactwo, przysposobienie oraz fakt wspólnego zamieszkiwania. Członkiem rodziny, osobą najbliższą, zgodnie z Kodeksem karnym jest „małżonek, wstępny, zstępny, rodzeństwo, powinowaty w tej samej linii lub stopniu, osoba pozostająca w stosunku przysposobienia oraz jej małżonek, a także osoba pozostająca we wspólnym pożyciu"10. Kluczowe jest tu wspólne pożycie - termin zarezerwowany dla małżonków i w pewnym swoim aspekcie związany z bliskością cielesną, ale nie tylko. Oznacza on bowiem także wspólnotę gospodarczą, emocjonalną i duchową. Ta prawna definicja nie wyklucza poszerzenia definicji członka rodziny o inne niespokrewnione osoby.

Takie poszerzenie dokonuje się we współczesnych koncepcjach socjologicznych. Tradycyjnie w socjologii rodzina rozumiana jest jako mała grupa społeczna (tworząca małżeństwo i generująca więzi pokrewieństwa) - „podstawowa komórka społeczna” - lub jako grupa pierwotna (oparta na intymności i socjalizacji), a także jako uniwersalna instytucja społeczna (utrwalona w tradycji wszystkich kultur - powszechnik kulturowy). ${ }^{11}$ Może być również ujmowana jako „komórka” społeczna, jak chciał tego George Murdock ${ }^{12}$. Zgodnie z tą tradycją rodzina nuklearna to matka, ojciec oraz ich dzieci. Kontynuacją tej teorii było nuklearne rozumienie rodziny, które warunkowało przetrwanie społeczeństwa industrialnego ${ }^{13}$. Współcześnie socjologowie odchodzą od definicji „komórkowej” czy „nuklearnej” w kierunku bardziej elastycznych jej form, podkreślając, że rodzina jest procesem, a nie sztywną strukturą, niezmienną w czasie. To, co ważne i relatywnie niezmienne, to ta cecha rodziny, która jest związana z posiadaniem dzieci.

Przemiany rozumienia rodziny można uzasadnić po części teorematem Bernardesa, odnoszącym się do teorematu Thomsona. Ten ostatni w parafrazie brzmi mniej więcej tak: jeśli człowiek definiuje coś jako realne, to jest to

9 Do kręgu członków rodziny uprawnionych do renty rodzinnej po zmarłym zaliczono: dzieci własne i przysposobione, pasierbów, wnuki i rodzeństwo przyjęte na wychowanie i utrzymanie przed osiągnięciem pełnoletniości, dzieci przyjęte na wychowanie w rodzinie zastępczej, rodziców oraz małżonka (wdowę lub wdowca) - nawet wówczas, gdy przed śmiercią orzeczony został rozwód lub separacja - art. 65-71 Ustawy z dnia 17 grudnia 1998 roku o emeryturach i rentach z Funduszu Ubezpieczeń Społecznych (Dz. U. z 2004 r., Nr 39, poz. 353 ze zm.).

10 Art. $115 \$ 11$ Ustawy z dnia 6 czerwca 1997 r. - Kodeks karny (Dz. U. Nr 88, poz. 553, z późn. zm.1).

11 T. Szlendak, Socjologia rodziny..., dz. cyt., s. 94.

12 Tamże, s. 96.

13 Tamże, s. 97. 
realne w swoich konsekwencjach, co de facto oznacza, że świat wygląda tak, jak się ludziom wydaje. Teoremat Bernardesa sprowadza się do tego, żeby odrzucić naukowy koncept rodziny, który często nie przystaje do rzeczywistości i poniekąd nagina ją do określonych teorii lub ideologii. Zamiast tego należy badać to, co podmioty życia społecznego same uznają za rodzinę. Stąd postulat Irene Levin, żeby tworzyć mapy rodzinne. Wtedy w jej zarysie znajdą się przeróżne postaci życia rodzinnego, począwszy od „naturalnych” krewnych dzieci, rodziców, rodzeństwa, poprzez partnerów życiowych, teściów, wnuki, kuzynów, aż po przyjaciół, byłych partnerów, partnerów dzieci czy zwierzęta domowe. W zakres rodziny wchodzą wszyscy ci, których sami uznajemy za rodzinę ${ }^{14}$. W efekcie tego badacze rodziny proponują jej innowacyjną definicję, która ma bardziej przystawać do jej dynamiki i procesualności niż tradycyjne ujęcia strukturalne. Otóż rodzina to „grupa krewnych, powinowatych, przyjaciół oraz innych aktorów skupionych wokół rodzica z dzieckiem, najczęściej matki"15

W oparciu o takie rozumienie można wprowadzać inne podziały i typologie rodzin, ze względu na ich skład - np. rodziny seniorskie, rodziny nuklearne, rodziny, wielopokoleniowe; ze względu na miejsce ich zamieszkania - wiejskie, miejskie, wielkomiejskie; można też opisywać rodziny przez pryzmat problemów w nich występujących - rodziny z problemem uzależnienia, przemocy, niepełnosprawnością, zaburzeniami psychicznymi, bezrobotne, niewydolne wychowawczo, cudzoziemskie itp.

\section{Nowa definicja rodziny seniorskiej}

Rodzina seniorska w rozumieniu autorki niniejszego tekstu może mieścić się w alternatywnych formach życia rodzinnego, opisywanych w literaturze tematycznej i dyskutowanych w debatach akademickich. Pośród takich form, jak: kohabitacja (konkubinat, związek partnerski/związek nieformalny), rodzina monoparentalna, rodzina zrekonstruowana, rodzina-układanka ( $p a-$ tchwork family), rodzina na odległość (LAT), rodzina bez dzieci (DINKS), rodzina nomadyczna, zastępcza i rodzina przybrana/adopcyjna oraz „układy sieciowe” seniorów, grona przyjacielskie („kółko przyjacielskie” - „friends”) czy single, jest miejsce na rodzinę seniorską.

Proponowana definicja takiej rodziny brzmi: rodzinę seniorską stanowi osoba lub osoby w wieku poprodukcyjnym oraz otoczenie tej osoby/osób, któ-

14 Tamże, s. 105-107.

15 Tamże, s. 114. 
re bierze udział w prowadzeniu przez seniora gospodarstwa domowego. Chodzi zarówno o osoby spokrewnione z seniorami, jak i niespokrewnione, które biorą udział zaspokajaniu potrzeb rodziny seniorskiej (nawet jeśli jest to jednoosobowe gospodarstwo domowe seniorskie), a także mogą korzystać ze świadczeń, otrzymywanych przez seniora/seniorów oraz angażować własne zasoby (także te niematerialne).

Rodzina seniorska rozumiana jest jako otoczenie seniora, które organizuje, zapewnia, bądź usamodzielnia seniorów/seniora, pomaga w dostarczaniu wszystkich niezbędnych i dodatkowych zasobów, służących budowaniu jak najwyższej jakości życia rodziny seniorskiej. Rodzina seniorska zgodnie z zasadą subsydiarności w swoich celach horyzontalnych ma za zadanie takie wsparcie seniora, żeby był on w jak najwyższym stopniu aktywny, samodzielny, dysponował wysokim potencjałem udziału w życiu społecznym, wysoką świadomością swoich praw i potrzeb oraz zasobami, służącymi zaspokojeniu własnych potrzeb, czyli będzie konsumentem usług ( $w$ tym społecznych). Jeśli otoczenie osoby starszej nie jest w stanie takich celów osiągać, w życie seniora wkracza z jednej strony państwo, a z drugiej sektor prywatny, z ofertą usług społecznych. Członkowie rodziny seniorskiej wyręczają państwo, ale też korzystają na więzi $\mathrm{z}$ seniorem. W rodzinach spokrewnionych $\mathrm{z}$ seniorem często zdarzają się sytuacje, że cała rodzina jest utrzymywana ze świadczenia osoby starszej (szczególnie $w$ rodzinach $\mathrm{z}$ dysfunkcjami $\mathrm{w}$ funkcjonowaniu społecznym). Podobna sytuacja, tylko mniej dysfunkcyjna, może być w rodzinie seniorskiej niespokrewnionej z osobą starszą.

U podstaw przywołanej definicji leży odniesienie do gospodarstwa domowego jako kluczowej cechy rodziny. Jest to definicja o charakterze demograficznym, gdyż we wszelkich statystycznych pomiarach rodzin łatwiej jest badać gospodarstwa domowe rozumiane jako „dowolny zestaw ludzi zamieszkujących jeden dom i wspólnie go utrzymujących"16. Nawet jeśli w gospodarstwie domowych zamieszkuje jeden senior, to osoba/osoby wspierające go w codzienności stają się członkami jego rodziny w znaczeniu definicji rodziny z Ustawy o pomocy społecznej, gdyż przyczyniają się do jego dobrostanu . Zatem nie fakt zamieszkiwania, ale właśnie troska o dobrostan seniora w bardzo szerokim sensie może być jednym z kryteriów przynależności do rodziny seniorskiej.

Dla oceny skuteczności rodziny seniorskiej dobrze jest zbadać poziom zaspokojenia potrzeb seniora - począwszy od potrzeb fizycznych, przez emocjonalne, po psychiczne i duchowe. Jednocześnie członkowie tej rodziny w sposób adekwatny do dobrostanu psychicznego i fizycznego aktywizują seniora, przestrzegają trzech kluczowych wartości: prawa do samostanowienia, podmioto-

16 Tamże, s. 103. 
wego traktowania oraz prawa do autonomii i wolności decydowania i wybierania. Można zatem stwierdzić, że nie zawsze pokrewieństwo, ale relacja $\mathrm{z}$ seniorem i stosunek do niego będą decydować o wchodzeniu w skład rodziny seniorskiej. Do jej członków mogą być zatem zaliczeni ludzie niespokrewnieni z seniorem i w ujęciu tradycyjnym zupełnie mu obcy. Ich motywacja może być różnorodna - emocjonalna bądź finansowa - ale tak naprawdę nie ma ona znaczenia w sytuacji, gdy potrafią w taki sposób zaangażować się w opiekę i współdziałanie z seniorem, które go nie rani, a raczej sprzyja jego rozwojowi i motywacji do dalszego życia.

Wśród naczelnych funkcji rodziny, które wymienia tradycyjna socjologia $^{17}$, dla rodziny seniorskiej w rozumieniu określonym w niniejszym tekście ważne są funkcje: emocjonalna, opiekuńcza, ekonomiczna, integracyjno-kontrolna i rekreacyjno-towarzyska, przy czym kluczowe wydają się dwie pierwsze. Funkcja opiekuńcza zabezpiecza niesamodzielnych członków rodziny w przypadkach nieradzenia sobie z trudnościami lub w sytuacji niezaspokojenia potrzeb. Realizacja tej funkcji wobec seniora odsyła do zjawiska opieki nieformalnej, sprawowanej nad seniorami w Polsce głównie przez kobiety, członkinie rodzin seniora ${ }^{18}$. Tradycyjny model wspierania osób starszych odwoływał się do silnych struktur rodzinnych, a odpowiedzialność za opiekę nad seniorami (oraz dziećmi) należała do kobiet, co wynikało z uwarunkowań kulturowych oraz z podziału obowiązku między kobietami i mężczyznami w rodzinie. Badania Anny Kotlarskiej-Michalskiej z lat 80. potwierdzały to zjawisko pomimo dość szerokiego zakresu działania placówek opiekuńczych i instytucji pomocy społecznej. Rodziny przewlekle chorych, inwalidów oraz osób starszych świadczyły usługi opiekuńcze, wykonując takie czynności domowe, jak: sprzątanie, gotowanie, pranie, pomoc w załatwianiu spraw urzędowych, oraz dawały wsparcie duchowe. Wówczas $87 \%$ osób starszych otrzymywało opiekę i pielęgnację od rodziny, a 13\% od sąsiadów lub instytucji. Najważniejszymi formami pomocy ze strony rodziny były opieka i pielęgnacja w chorobie, co było zgodne z oczekiwaniami osób starszych (tylko $2 \%$ osób po 60 . roku życia oczekiwało w takich sytuacjach pomocy pielęgniarki) ${ }^{19}$. Prognozy związane z opieką nad seniorami, uwzględniające czynniki migracji zarobkowej, wydłużania się życia oraz dzietności, wskazują na to, że coraz więcej seniorów będzie potrzebowało opieki instytucjonalnej.

${ }_{17}$ T. Szlendak, Socjologia rodziny, dz. cyt., s. 116-117.

18 M. Rosochacka-Gmitrzak, Wsparcie opiekunów nieformalnych - w stronę równowagi społecznych oczekiwań i opiekuńczych możliwości rodzin, [w:] M. Racław, Publiczna troska, prywatna opieka. Społeczności lokalne wobec osób starszych, Warszawa 2011, s. 140-141.

19 A. Kotlarska-Michalska, Funkcja opiekuńczo-zabezpieczajaca wielkomiejskich rodzin pracowniczych, Poznań 1990. 
Istnieje wiele badań i analiz, które potwierdzają, że w Polsce opiekę nad osobami starszymi sprawują głównie członkowie rodziny ${ }^{20}$. Jednym z najbardziej przekonujących jest badanie przeprowadzone w ramach projektu Eurofamcare ${ }^{21}$ na zlecenie Ministerstwa Pracy i Polityki Społecznej, zgodnie z wynikami którego w Polsce liczba opiekunów nieformalnych wynosi około 2 miliony. Nie wchodząc za bardzo w szczegóły przyczyn i konsekwencji takiej sytuacji, pragnę zasygnalizować fakt obciążenia opieką nad seniorem opiekunów nieformalnych, pochodzących z jego najbliższego otoczenia. Wiąże się z tym obciążenie, cechujące pokolenie określane mianem pokolenie sandwich (sandwich generation), a mianowicie obowiązek podwójnej opieki nad osobami zależnymi - jednocześnie nad dziećmi i starzejącymi się rodzicami. W sytuacji, w której opiekun będzie musiał jeszcze pracować, wytworzy się luka opiekuńcza, którą zapełniać będą osoby inne niż członkowie rodziny. Mogą to być sąsiedzi, przyjaciele, ale też „najemnicy”. Jeśli takiej osobie uda się zyskać zaufanie seniora, stworzyć z nim relację i w jakimś sensie „zastąpić mu rodzinę”, stanie się wtedy członkiem „nowej rodziny seniorskiej” zgodnie z przytoczoną definicją. Taka perspektywa jest bardzo prawdopodobna w sytuacji, kiedy polska tradycja opieki nad członkami rodziny dość rzadko lokuje te zadania w instytucjach opiekuńczych, takich jak domy pomocy społecznej czy inne instytucjonalne formy wsparcia. Zatem istnieją uwarunkowania społeczne dla rozszerzenia rodziny seniora o osoby niespokrewnione.

Należy zauważyć, że rodzina jest również wartością w innym niż czysto aksjologiczne rozumienie. Dobitnie pokazał to Gary S. Becker, laureat Nobla w dziedzinie ekonomii w 1992 roku. Podstawowym założeniem teorii Beckera, podobnie jak całej szkoły chicagowskiej, jest teoria racjonalnego wyboru, według której ludzie postępują racjonalnie, a to wymaga od nich przestrzegania pewnych praw, które wiążą się z teorią maksymalizacji użyteczności. Becker wprowadził do ekonomii pojęcie „inwestycja w człowieka”. Rodzina w głównej mierze obciążona jest kosztami tej inwestycji, dlatego że wychowuje dzieci. To właśnie liczne społeczeństwa, które produkują wysoki poziom „kapitału społecznego” poprzez wspieranie rodziny, mogą oczekiwać, że będą się rozwijały kulturowo i gospodarczo. Becker oszacował, że wartość pracy wykonywanej w rodzinie i na jej rzecz sięga poziomu 30\% dochodu narodowego. Dotyczy to usług edu-

20 Por. m.in. Seniorzy w społeczeństwie polskim, red. M. Kuciarska-Ciesielska, GUS, Warszawa 1999; Polska starość, red. B. Synak, Gdańsk 2002; B. Szatur-Jaworska, Ludzie starzy i starość w polityce społecznej, Warszawa 2000; J. Perek-Białas, Opieka nad ludźmi starymi: społeczeństwo, państwo, rynek, [w:] Wokół zagadnień gospodarki niereformowalnej, red. A. Karwińska, A. Surdej, Kraków 2004.

$21 \quad$ J. Perek-Białas, Urynkowienie usług opiekuńczych dla osób starszych w Polsce - możliwości i ograniczenia, [w:] Publiczna troska, prywatna opieka..., dz. cyt., s. 61. 
kacyjnych, medycznych i opiekuńczych oraz edukacji zdrowotnej, świadczonych przez rodziców na rzecz dzieci, a także usług na rzecz funkcjonowania gospodarstwa domowego, za co żaden z członków rodziny nie pobiera wynagrodzenia. Ten rodzinny system usług, zorganizowany poza rynkiem otwartym, generuje oszczędności, które prowadzą do koncentracji kapitału. Kapitał rodzinny, zgromadzony w taki sposób, trafia prędzej czy później na rynek, napędzając przedsiębiorczość, rozwój gospodarczy, ale też rozwój kulturowy. Taki mechanizm działa tylko w sytuacji nieograniczania wolnego rynku oraz kulturowego utożsamienia się społeczeństwa $\mathrm{z}$ wartościami rodzinnymi ${ }^{22}$. Ten model można z powodzeniem przełożyć na wytwarzanie kapitału społecznego w rodzinie seniorskiej, nieważne czy spokrewnionej, czy nie z osobą starszą.

Jak zatem widać, dostrzeganie w funkcjonowaniu rodziny wartości samej w sobie może stać się praktycznym aksjomatem udzielania wsparcia rodzinie seniorskiej, która ma szansę na produkcję kapitału społecznego seniora. Takiego wsparcia poza sektorem pozarządowym, który niestety póki co pełni rolę marginalną w tej pomocy, udziela sektor publiczny.

W kontekście poszerzenia granic rodziny seniorskiej należy zwrócić uwagę na jeszcze jeden element, który stanowi zagrożenie, ale jednocześnie może być ogromnym zasobem dla seniora. Otóż każda relacja, aby nie była toksyczna, musi funkcjonować we względnej równowadze dawania i brania. To dotyczy także relacji seniora i członka jego rodziny. Ta wymiana może mieć charakter ekonomiczny, ale też emocjonalny. Ważne jest, żeby obie strony korzystały z wzajemnych powiązań, gdyż jeśli jedna strona będzie dawała więcej, może pojawić się agresja, frustracja i odrzucenie. Jeśli ta relacja pozostanie w równowadze, wtedy będzie można mówić o budowaniu kapitału społecznego osoby starszej, dla której relacje rodzinne będą wzmocnieniem i impulsem do życia i rozwoju, a nie kolejnym niszczycielskim czynnikiem życiowym. Rolą członka rodziny seniora jest wydobycie zasobów seniora - jego wiedzy, doświadczenia, umiejętności, emocji, ale też pracy na rzecz innych - po to, aby senior czuł się przydatny i aby chciało mu się nie ustawać w działaniu na rzecz siebie lub innych.

Jakie są konsekwencje tak szerokiego ujęcia rodziny seniorskiej? Po pierwsze, poprawia się subiektywna sytuacja seniorów, zarówno ta psychiczna i emocjonalna, jak i społeczna. Stała opieka, ale też relacja zbudowana na zasadzie troski, wsparcia i relatywnej autonomii seniora powoduje ograniczenie poczucia osamotnienia, nieprzydatności, zbędności egzystencjalnej. Nawet jeśli seniorem opiekuje się osoba spoza rodziny, ostatecznie systematyczność tego wspar-

22 Por. G. S. Becker, Nieoczywistości. Ekonomiczna teoria wszystkiego, Warszawa 2013; tenże, Ekonomiczna teoria zachowań ludzkich, Warszawa 1990. 
cia może spowodować powstanie więzi zastępczej. To prowadzić może mimo wszystko do poprawy społecznego funkcjonowania seniora, dla którego członek/członkowie rodziny są dogodnym zapleczem, po to, żeby mógł on podejmować wysiłek związany z rozwojem w okresie życia, który z tym rozwojem się nie kojarzy.

Z tego może wynikać druga konsekwencja, a mianowicie przeobrażenie się więzi rodzinnych i społecznych. W sytuacji wspieraniacia seniora przez osoby niespokrewnione zanikają więzi naturalne, ale powstają nowe ich formy, swoista „nowa wspólnota”. Może ona być złożona z rówieśników - osób niespokrewnionych, ale dzielących doświadczenie starości. Nowa wspólnota opiera się na więzach, które docelowo mogą prowadzić do wymiany dóbr - począwszy od wysiłku fizycznego, zasobów materialnych, opieki, wiedzy, czasu, zaangażowania, jednoczenia się, aż do bliskości. W niektórych przypadkach jakość tych więzi może być lepsza niż więzi pomiędzy członkami rodziny. Relacja rodzinna zawiera bowiem implicite przekonanie o tym, że wszelkie zgromadzone przez seniora dobra powinny pozostać w gestii i do dyspozycji członków rodziny, natomiast więzi budowane poza relacjami rodzinnymi wymagają autentycznego zaangażowania, aby ich jakość była porównywalna.

W końcu poszerzona definicja rodziny seniorskiej, o ile okaże się konkurencyjna dla dotychczasowej formuły rodziny osoby starszej, w dalszej perspektywie będzie z pewnością wymagała swoistej legalizacji w postaci właściwych udogodnień prawnych. Obecnie prawo zawiera nieliczne zapisy dotyczące wsparcia opiekunów osób starszych, dominująca jest w nim pozycja rodziny naturalnej. Być może rekonstruowane więzi rodzinne będą w przyszłości wymagały ochrony, o ile nie staną się obszarem pojawiających się wobec seniorów nadużyć, szczególnie tych związanych z wyłudzaniem majątku, zawłaszczaniem uposażenia seniora czy opieką nad seniorem wyłącznie dla korzyści finansowych (np. poprzez pobieranie świadczenia pielęgnacyjnego czy przejmowania jego poborów). W tym kontekście do uregulowania byłyby na przykład kwestie dziedziczenia, wspólnego rozliczania się (podobnie jak w przypadku wspólnych rozliczeń z dziećmi) czy zasiłków opiekuńczych dla osób niespokrewnionych. Członkowie rodziny seniora nadal bowiem, tak jak dotychczas, wyręczaliby w funkcjach opiekuńczych państwo, pomimo wieloletniego płacenia przez seniora podatków i składek ubezpieczeniowych. Do uregulowania pozostawałaby również kwestia zapobiegania nadużyciom ze strony członków rodziny, a w zasadzie nadzór nad poprawnością relacji, zarówno w rodzinie spokrewnionej, jak i niespokrewnionej. Ta ostatnia kwestia zdaje się być słabą stroną systemu opiekuńczego państwa i niezależnie od definicji rodziny seniorskiej pozostaje bardzo drażliwym tematem związanym z ujawnianiem wszelkich nadużyć wobec seniorów. 


\section{Podsumowanie}

Rodzina w życiu osób starszych jest niezwykle ważnym elementem ich dobrostanu. Może to wynikać z faktu, że większość seniorów, którzy posiadają dzieci, traktuje je, w sposób świadomy bądź nieświadomy, jako swoistą inwestycję, zabezpieczenie na późne lata swojego życia. Wychowują dzieci, mając nadzieję, że na starość będą mogli liczyć na ich bezwarunkowe wsparcie. Niestety, coraz częściej sytuacja ekonomiczna, czasami okoliczności losowe, ale też uwarunkowania kulturowe sprawiają, że ta nadzieja zawodzi. Wtedy senior skazany jest albo na instytucjonalne wsparcie ze strony państwa, albo na gorycz opuszczenia. Taka sytuacja wymusza podejmowanie nowatorskich inicjatyw w celu organizowania opieki dla seniora, np. w taki sposób, aby nie tracił on swojej niezależności, środowiska życia, a jednocześnie rekompensował sobie utracone lub osłabione więzi z rodziną inną formą relacji z opiekunem. W tym sensie poszerzenie definicji rodziny seniorskiej stwarza warunki do tego, by docenienić zaangażowanie obcych pozornie osób, które są w stanie zaangażować się w pomoc seniorowi w taki sposób, żeby osoba starsza mogła jak najdłużej pozostać we własnym domu, mając jednocześnie dostęp do dóbr i usług, zaspokajających jej potrzeby. Od samego seniora zależy, czy to zaangażowanie określi jako rodzinne, czy też nie.

\section{Bibliografia}

Becker G. S., Ekonomiczna teoria zachowań ludzkich, Warszawa 1990.

Becker G. S., Nieoczywistości. Ekonomiczna teoria wszystkiego, Warszawa 2013.

Jak będzie wyglądała starość dzisiejszych 30-latków? Rozmowa z prof. Piotrem Błędowskim, http://weekend.gazeta.pl/weekend/1,138262,18364753,jak-bedzie-wygladala-staroscdzisiejszych-30-latkow-prof-piotr.html (14.10.2015).

GUS, Podstawowe informacje o rozwoju demograficznym Polski do 2014 roku, Warszawa 2015.

GUS, Prognoza ludności na lata 2014-2050, Warszawa 2014.

Kodeks karny (Dz. U. Nr 88, poz. 553, z późn. zm.).

Kotlarska-Michalska A., Funkcja opiekuńczo-zabezpieczająca wielkomiejskich rodzin pracowniczych, Poznań 1990.

Seniorzy w społeczeństwie polskim, red. M. Kuciarska-Ciesielska, GUS, Warszawa 1999.

Perek-Białas J., Opieka nad ludźmi starymi: społeczeństwo, państwo, rynek, [w:] Wokół zagadnień gospodarki niereformowalnej, red. A. Karwińska, A. Surdej, Kraków 2004.

Perek-Białas J., Urynkowienie usług opiekuńczych dla osób starszych w Polsce - możliwości i ograniczenia, [w:] Publiczna troska, prywatna opieka. Społeczności lokalne wobec osób starszych, red. M. Racław, Warszawa 2011. 
Rosochacka-Gmitrzak M., Wsparcie opiekunów nieformalnych - w stronę równowagi społecznych oczekiwań i opiekuńczych możliwości rodzin, [w:] M. Racław, Publiczna troska, prywatna opieka. Społeczności lokalne wobec osób starszych, Warszawa 2011.

Ryś M., Kształtowanie się poczucia własnej wartości i relacji z innymi w różnych systemach rodzinnych, „Kwartalnik Naukowy Fides et Ratio”, 2(6) 2011.

Polska starość, red. B. Synak, Gdańsk 2002.

Szatur-Jaworska B., Ludzie starzy i starość w polityce społecznej, Warszawa 2000.

Szlendak T., Socjologia rodziny. Ewolucja, historia, zróżnicowanie, Warszawa 2012.

Szukalski P., Małżeństwa zawierane w starszym wieku - szkic demograficzny, [w:] Starość darem, zadaniem i wyzwaniem, red. A. Zych, Sosnowiec-Dąbrowa Górnicza 2014.

Ustawa z dnia 12 marca 2004 roku o pomocy społecznej (Dz. U. z 2 lipca 2008 Nr 115 poz. 728 - tekst jednolity).

Ustawa z dnia 17 grudnia 1998 roku o emeryturach i rentach z Funduszu Ubezpieczeń Społecznych (Dz. U. z 2004 r. Nr 39 poz. 353 ze zm.).

Ustawa z dnia 25 lutego 1964 roku Kodeks rodzinny i opiekuńczy (Dz. U. z 1964 r. Nr 9, poz. 59 ze zm.). 
A. Uniwersytet Papieski T.5. Jana Pawła II 